\title{
Impact on energy saving and thermal comfort through the application of expanded polyurethane thermal insulation in Panama
}

\author{
Orlando Aguilar P., Bachelor's in Mechanical Engineering student ${ }^{1}$, José Mendoza Bachelor's in Mechanical \\ Engineering student ${ }^{1}$, Luis Mogollón, M.S. in Electrical Engineering ${ }^{2}$, Félix Henríquez, Doctorate in Environmental \\ Engineering ${ }^{3}$, and Orlando Aguilar G., Doctorate in Biological and Agricultural Engineering (Ph.D $)^{4}$ \\ ${ }^{l}$ Mechanical Engineering student, Universidad Tecnológica de Panamá, Panamá, orlando.aguilar1@utp.ac.pa, \\ jose230m@gmail.com \\ ${ }^{2}$ Investigator at CINEMI, Universidad Tecnológica de Panamá, Panamá, luis.mogollon@utp.ac.pa \\ ${ }^{3}$ Director of CINEMI, Universidad Tecnológica de Panamá, Panamá, felix.henriquez@utp.ac.pa \\ ${ }^{4}$ Director of Research, Universidad Tecnológica de Panamá, Panamá, orlando.aguilar@utp.ac.pa
}

\begin{abstract}
Air conditioning systems are used every day on a global scale in a search for comfort, especially in places with very hot and humid climates. Panama classifies as one of those, therefore, the use of air conditioning systems attributes to a big part of nationwide electricity consumption. As the country grows, more of these systems are used daily in residential and labor sectors, and this takes a toll on the nationwide consumption of electricity. Part of the country's strategy is increasing the energy generation capabilities, but the rational and efficient use of the energy that's already available could substantially help the energy situation in the country. This research focuses on evaluating the viability of the use of polyurethane based thermal insulation in Panama, with and without the use of air conditioning systems, to evaluate the impact of this technology in the human comfort and in the electricity bill payed for consumers in Panama. Various tests were conducted to evaluate different aspects such as decrease in consumption and temperature gain inside experimental houses. Test results indicate a 44\% decrease in electricity consumption due to the use of air conditioning systems under the installation of polyurethane insulation on ceiling and walls. This directly translates into a reduction of the cost of electric bills in homes and offices and may positively impact on the national electric energy demand.
\end{abstract}

Keywords-Thermal Insulation, Expanded Polyurethane, Energy Efficiency, Air Conditioning,

\section{INTRODUCTION}

Panama is a country with a tropical climate, which is characterized by hot days, for the year 2019 , the average of the maximum temperatures obtained was $36.5^{\circ} \mathrm{C}$ alongside an average humidity of $75.7 \%$, with peaks of up to $38^{\circ} \mathrm{C}$, and $89.9 \%$ respectively [1], [2]. These climatic conditions do not favor human comfort within homes and offices [3] [4]. Reason that promotes the use of air conditioning systems, especially in the labor and residential sector. In the labor sector, thermal comfort becomes an important factor as mentioned above for the performance of workers. In the residential sector, on the other hand, it plays an indispensable role for comfort, quality of life among other factors such as the amount rest required.

The ANSI/ASHRAE Standard 55 defines thermal comfort as "the condition of mind that expresses satisfaction with the thermal environment" [5], and it is directly affected by

Digital Object Identifier (DOI)

http://dx.doi.org/10.18687/LACCEI2020.1.1.231

ISBN: 978-958-52071-4-1 ISSN: 2414-6390 temperature, humidity, wind speed, mean radiant temperature, interior air quality and sound and vibration levels. The main parameter being temperature [6]. These situations cause much of the energy consumption of these sectors in Panama to be used only in air conditioning, increasing the national energy demand exponentially, this is a phenomenon that no only affects Panama, but other parts of the world as well [7]. Based on the problem raised, some questions arise such as: Has the search for solutions to reduce high energy demand been considered? Does consumption only depend on electrical equipment, or does infrastructure play a role in the performance and efficiency of the energy used? Could the use of thermal insulators decrease the energy consumption of homes and offices? What has the greatest impact on heat transfer in buildings: walls, windows or roof? By making use of thermal insulators on walls and ceilings, to what extent does each contribute to the increase in efficiency of houses and offices? Is the investment of thermal insulation in buildings and houses already built feasible? These questions motivate the search for solutions, by performing the proposed evaluations.

The use of thermal insulation may contribute to the solution of the problem. These insulations could reduce energy consumption in the short term, in this way, it could represent significant long-term money savings [8]. Under this perspective, it is considered pertinent to carry out an investigation whose purpose is to evaluate the heat gain and its impact on the energy efficiency of a construction by making use of thermal insulation. When determining, how feasible is the use of this technology in the Republic of Panama, we would have an option of a concrete solution to reduce the high energy demand suffered by the country, as well as save consumers money.

These evaluations are necessary to consider the future use of materials with insulating properties in any residential or industrial construction in a mandatory manner, where there are regulations at the national level in order to have efficient buildings thus achieving significant national energy savings. This project focuses on the evaluation of heat gain conditioned by the use or not use of insulation. The impact of heat gain

$18^{\text {th }}$ LACCEI International Multi-Conference for Engineering, Education, and Technology: "Engineering, Integration, and Alliances for a Sustainable Development" "Hemispheric Cooperation for Competitiveness and Prosperity on a Knowledge-Based Economy", 27-31 July 2020, Virtual Edition. 
and energy savings of a covered house with insulation in walls and roof, compared to an identical house without insulation, was evaluated. This was achieved based on the conditions of ambient temperature, humidity and radiation, which were measured, creating a database where a series of parallel evaluations can be made, thus being able to analyze the effects of each condition.

The development of the experimentation occurred between March 2019 and January 2020, this period included the design of the experiment, the installation process of the measuring equipment, the tests done to said measuring equipment, the collection of data and its analysis. This experiment was carried out in test houses built for this purpose on the grounds of the Universidad Tecnológica de Panamá (UTP) at the Tocumen Headquarters.

\section{MATERIALS AND METHODOLOGY}

\section{A. Samples and Equipment}

The thermal insulation analysis was carried out on two experimental samples, each of which have similar structural characteristics, and they differ only in that one of them has thermal insulation in all four walls and the ceiling, while the other does not. The first sample is the control and consists of a $9 \mathrm{~m}^{2}$ space with one window and a security door on the north wall. This wall is taller than the rest, while the south wall is the shortest, this results in a roof that slants in one way from north to south. The walls of the house are built with the typical materials used for construction in Panama, which are 4 in cinder blocks, which are fabricated with sand, cement, and stones. The roof is made up of 26-gauge zinc sheets with 42 by 16 in canals. It has a 9000 BTU split air conditioning system that can be programmed for automatic on and off. The second house is built identical to the first one, but as was mentioned before, this one has thermal insulation on all four walls and under the ceiling. The polyurethane panels are Stiferite GTC polyurethane thermal insulation. This insulating panel has a thickness of $80 \mathrm{~mm}$ with a thermal conductivity of $0,022 \mathrm{~W} / \mathrm{m} \cdot \mathrm{K}$. The insulating panels are installed on the exterior of the walls, with vapor barriers between each panel and the cement blocks of the wall. On the outside, the panels were coated with a special sealer and then painted over with anti-mold paint. Both houses have an electrical outlet on one wall and a lightbulb socket on the roof in the middle of the house.

There are many measuring instruments utilized in the tests, but the two main ones are the energy measurement devices, and the system made up of master-slave temperature dataloggers and their respective thermocouples. The energy measurement devices utilized were CrocSee CRS-022B, these devices give readings of voltage, amperage, wattage, accumulated consumption in $\mathrm{kWh}$, and power factor. These instruments are connected to the breaker panel of each house, specifically to the breaker that handles the current of the air conditioning systems. The temperature dataloggers systems consist of one master unit per house, each one of these master units is connected to six slave units with LAN cables. In turn, each of these slave units can hold up to ten thermocouples connected with LAN cables, which in this case are model DS18B20, adding up to a total of sixty sensors in each house, which are distributed between the inside and the outside of each house. The whole system was designed, programmed and built in the UTP specifically for this project. The user interface consists of a screen in which the operator can connect to each individual master via a local Wi-Fi connection, and modify different aspects of the system such as: sampling time, active slave units and other settings, as needed.

\section{B. Sampling}

There are six different tests in the whole of the project, but this paper is going to focus on two. This first test lasts 24 hours and has four repetitions. It focuses on measuring the amount of time each house stays inside the set range of temperatures defined as the comfort zone for Panama in the Resolution N. 3142 of November 17 ${ }^{\text {th }}, 2016$ [9], which stipulates the range of temperatures allowed for thermal comfort to be between $23.5^{\circ} \mathrm{C}$ and $28.5^{\circ} \mathrm{C}$. For this test, the temperature was measured inside both houses for the complete duration of the test, without the usage of the split air conditioning system. The temperature was also measured on the outside, to be able to compare the difference of temperature in each house. The second test featured in this paper is the power consumption test. For this, the split air conditioning systems of each house were turned on for a total of seven days, to measure the difference in power consumption between each one of the houses. This test can be directly translated into monetary savings for users of the thermal insulation.

\section{RESULTS AND DISCUSSION}

\section{A. Test One: No A/C}

There were two different analysis conducted for this test. The first one consisted in evaluating the amount of time that the temperature inside each house was out of the comfort zone that was previously established. The following table shows the results of each one of the days that the test was conducted. The term "RP1" refers to the control house, while "RP2" refers to the house with the thermal insulation.

Table 1. Test One: No A/C Results

\begin{tabular}{|c|c|c|c|c|c|}
\hline \multicolumn{2}{|c|}{ Date } & $04 / 10 / 19$ & $05 / 10 / 19$ & $06 / 10 / 19$ & $07 / 10 / 19$ \\
\hline \multirow{3}{*}{ RP1 } & Time & $10: 25: 27$ & $10: 38: 19$ & $3: 52: 09$ & 12:18:13 \\
\hline & $\begin{array}{c}T \text { max } \\
\left({ }^{\circ} \mathrm{C}\right)\end{array}$ & 31.6 & 31.05 & 28.72 & 31.64 \\
\hline & $\mathrm{T}$ avg $\left({ }^{\circ} \mathrm{C}\right)$ & 30.04 & 29.96 & 28.62 & 30.28 \\
\hline \multirow{3}{*}{ RP2 } & Time & $6: 25: 36$ & $12: 16: 57$ & $5: 36: 54$ & $12: 05: 16$ \\
\hline & $\begin{array}{c}\text { T max } \\
\left({ }^{\circ} \mathbf{C}\right)\end{array}$ & 28.95 & 29.05 & 28.61 & 29.19 \\
\hline & $\mathrm{T} \operatorname{avg}\left({ }^{\circ} \mathrm{C}\right)$ & 28.66 & 28.77 & 28.56 & 28.95 \\
\hline \multicolumn{2}{|c|}{$\Delta$ Time } & $3: 59: 51$ & NULL & NULL & $0: 12: 57$ \\
\hline \multicolumn{2}{|c|}{$\Delta \mathrm{T} \max \left({ }^{\circ} \mathrm{C}\right)$} & 2.65 & 2.00 & 0.11 & 2.45 \\
\hline \multicolumn{2}{|c|}{$\Delta \mathrm{T}$ avg $\left({ }^{\circ} \mathrm{C}\right)$} & 1.37 & 1.19 & 0.05 & 1.33 \\
\hline
\end{tabular}

Digital Object Identifier: (only for full papers, inserted by LACCEI).

ISSN, ISBN: (to be inserted by LACCEI).

$18^{\text {th }}$ LACCEI International Multi-Conference for Engineering, Education, and Technology: "Engineering, Integration, and Alliances for a Sustainable Development" "Hemispheric Cooperation for Competitiveness and Prosperity on a Knowledge-Based Economy", 29-31 July 2020, Buenos Aires, Argentina. 
Table \#1. shows the results of the test after the due analysis was performed using Microsoft Excel. Each of the columns represents a different repetition of the test. The rows represent the different criteria evaluated. The time row of each house represents the amount of time that the inside temperature of each house was out of the comfort zone, the $\mathbf{T}$ max and $\mathbf{T}$ avg represent the maximum and average temperature inside each house for each repetition. At the bottom of the table the differences between the insulated house and the control house are shown. The initial idea was to compare the amount of time that the temperature of each house is outside of the comfort zone, but that analysis turned out to be inconclusive because the results show that out of the four repetitions, in two of them the control house spent more time out of the comfort zone and in the other two the insulated house spent more time outside the comfort zone. These results only took into consideration the time, but the inside temperature of each house must also be taken into account.

As mentioned before, this second analysis takes into consideration both time and temperature. As shown in Figure $\# 1$., while the internal temperature from the control house (green) stays inside the comfort zone for a longer time than the insulated house (blue), the internal temperature from the control house is much higher in comparison to the insulated house during the second half of the day.

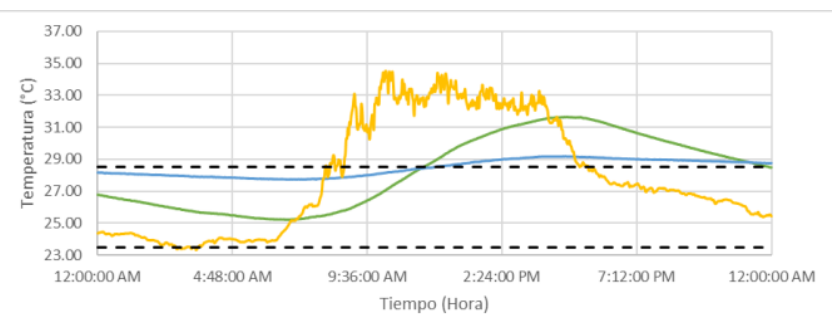



Figure 1. Internal vs. External Temperatures (07/10/2019), with comfort zone.

There was a need to join these two variables, so an area analysis was performed. The part of each line that goes above the superior limit of the comfort zone was isolated and plotted on its own (see Fig. \#2.). Then the area under the resulting curve was calculated, by integrating the $6^{\text {th }}$ grade polynomial equation for each graph. The upper and lower limits for the calculation of each integral were the time that the temperature went above and under the superior limit of the comfort zone, respectively. For simplicity purposes, a reference of $1=86400$ seconds was utilized to convert the time into a smaller number to make the calculations of the integrals with. The resulting magnitude was a number that directly correlates both the time

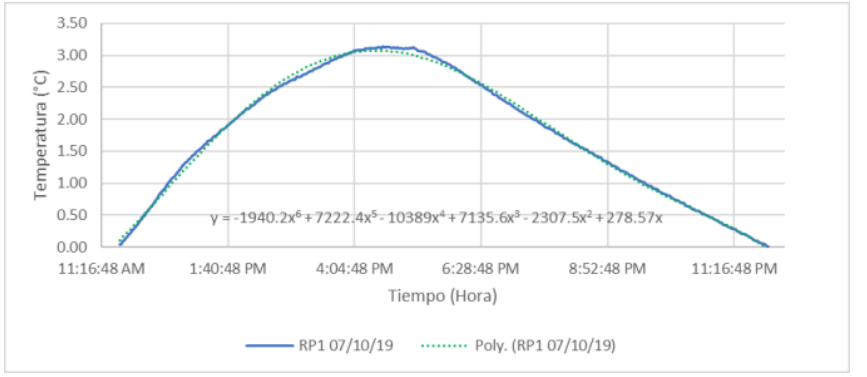

Figure 2. Internal Temperature out of comfort zone for RP1, on 07/10/19.

Table 2. Results of the area analysis.

\begin{tabular}{|c|c|c|c|c|c|}
\hline & & $\begin{array}{c}\text { Inferior } \\
\text { Limit }\end{array}$ & $\begin{array}{c}\text { Superior } \\
\text { Limit }\end{array}$ & $\begin{array}{c}\text { Evaluated } \\
\text { Integral }\end{array}$ & $\begin{array}{c}\text { Reduction } \\
\% \\
\end{array}$ \\
\hline \multirow{2}{*}{$4 / 10 / 19$} & RP1 & 0.439 & 0.874 & 0.735 & \multirow{2}{*}{$95.51 \%$} \\
\hline & RP2 & 0.514 & 0.782 & 0.033 & \\
\hline \multirow{2}{*}{$5 / 10 / 19$} & RP1 & 0.476 & 0.919 & 0.713 & \multirow{2}{*}{$80.64 \%$} \\
\hline & RP2 & 0.482 & 0.994 & 0.138 & \\
\hline \multirow{3}{*}{$6 / 10 / 19$} & & & & & \multirow{3}{*}{ NULL } \\
\hline & RP1 & 0.590 & 0.751 & 0.020 & \\
\hline & RP2 & 0.536 & 0.770 & 0.080 & \\
\hline \multirow{2}{*}{$7 / 10 / 19$} & RP1 & 0.484 & 0.997 & 0.904 & \multirow{2}{*}{$75.33 \%$} \\
\hline & RP2 & 0.496 & 0.999 & 0.223 & \\
\hline
\end{tabular}

The results show that in three out of the four repetitions of the test, the area under the curve for the insulated house is significantly smaller than that of the control house. The only exception to this is on the day $06 / 10 / 2019$, in which the exterior temperature was very cool compared to the other three days. On this day the cloud cover was dense, and there was rainfall during most of the day. The interior temperature of the control house is largely affected by the temperature on the exterior, so, since this day the exterior temperature was unusually low, the inside temperature of the control house was low too. The insulated house isn't largely affected by the temperature on the exterior, so it retained its relatively higher temperature compared to the outside. This might be very useful in a city with low temperatures, because it would decrease the cost of heating.

\section{B. Test Two: Electricity Consumption}

This is an energy consumption test. The air conditioning system of each house were turned on for a total duration of seven days, during which the energy consumption was measured with the CRS-022B. At the end of the seven days, a reduction percentage comparison was made, in which the consumption of the insulated house resulted to be $44 \%$ less than that of the control house, these results are like those of a similar study made in Mexico [10]. At the moment in which these measurements were made, the cost of electricity in medium consumption homes in this area $(301-750 \mathrm{~kW} / \mathrm{h})$ was $0.21686 \$ / \mathrm{kWh}[11]$, this means that the cost for running the air conditioning system in the control house was of $\$ 9.32$ and of $\$ 5.20$ for the insulated house. Considering a medium income home in Panama City with four air conditioning systems and an average monthly consumption of $550 \mathrm{kWh}$, this could translate into a yearly saving of around \$280, taking into account that air conditioning systems occupy on average $45 \%$ of the consumption of each household [12]. This reduction in electricity usage could contribute to a reduction of the country's electricity demand. These values are, of course, an approximation, because the cost of electricity varies every six months, as well as that the electric consumption of the air conditioning units varies according to factors like efficiency, weather and the thermal load in the inside of the house. 
Table 3. Results of the electricity consumption test.

\begin{tabular}{|c|c|c|c|}
\hline Test House & $\begin{array}{c}\text { Electricity } \\
\text { Consumption } \\
\text { (kWh) }\end{array}$ & $\begin{array}{c}\text { Cost of } \\
\text { Electricity } \\
\text { (Dollars) }\end{array}$ & \multirow{2}{*}{ Reduction \% } \\
\hline RP1 & 43 & 7.50 & \multirow{2}{*}{$44.18 \%$} \\
\hline RP2 & 24 & 4.19 & \\
\hline
\end{tabular}

\section{CONCLUSIONS}

The usage of polyurethane based thermal insulation is not something widely considered a solution for energy consumption reduction in the Republic of Panama, and as such its use should be promoted to increase energy efficiency in the country.

Under the conditions of this study, the use of polyurethane based thermal insulation can result in savings of $44.18 \%$ in electricity consumption from the use of air conditioning systems.

Utilizing polyurethane based thermal insulation could provide the benefit of increased thermal comfort without the usage of air conditioning systems.

The results of this study proved to be positive regarding the use of polyurethane based thermal insulation, however, it is recommended that future studies include the use of other organic insulating materials as test subjects, to develop a database of information containing the options for thermal viable insulation in the Republic of Panama.

\section{ACKNOWLEDGEMENT}

This study was made under the administration of the Electrical, Mechanical and Industrial Innovation and Research Center (CINEMI) of the Universidad Tecnológica de Panamá (UTP). Special thanks to Omar Cornejo, Orlando Melgar and Anthony García for their support in the development of this project.

The insulating material for this research was provided by STIFERITE, SpA.

\section{REFERENCES}

[1] Centro Nacional de Despacho, "Comportamientos del Sistema," Panamá, Panamá, 2019.

[2] Hidromet, "Datos Históricos," Panamá, Panamá, 2020.

[3] E. Urriola, "Índices de Confort Térmico en Panamá," Panamá, 2019.

[4] M. Morsy, "Effect of Thermal Insulation on Building Thermal Comfort and Energy Consumption in Egypt", Cairo, Egypt, 2018.

[5] ASHRAE, Thermal Environmental Conditions for Human Occupancy, 2017.

[6] W. Grondzik, Air Conditioning System Design Manual 2nd Edition, New Delhi: ELSEVIER INDIA, 2011.

[7] M. Khoukhi, "The impact of employing insulation with variant thermal conductivity on the thermal performance of buildings in the extremely hot climate", Al Ain, United Arab Emirates, 2019.

[8] F. J. C. d. Valle, Zona Variable de Confort Térmico, Barcelona: Universidad De Catalunya, Departamento de Construcciones Arquitectónicas, 2002.

[9] Gaceta Oficial, República de Panamá, "Resolución N³142, QUE ADOPTA LA GUÍA DE CONSTRUCCIÓN SOSTENIBLE PARA EL AHORRO DE ENERGÍA EN EDIFICACIONES Y MEDIDAS PARA EL USO RACIONAL EFICIENTE DE LA ENERGÍA, PARA LA CONSTRUCCIÓN DE NUEVAS EDIFICACIONES EN LA REPÚBLICA DE PANAMÁ," Panamá, 2016.

[10] R. Calderón, "Reducción del Consumo Eléctrico y $\mathrm{CO}_{2}$ mediante Sistemas de Ahorro y de Aislamiento Térmico aplicados en Viviendas en Zonas Áridas de México, Baja California, México, 2011

[11] Compañía de Distribución Eléctrica ENSA, "Pliegos Tarifarios," Junio 2019. [Online]. Available: https://www.ensa.com.pa/pliego-tarifariosegundo-semestre-2019.

[12] Y. Dominguez, "Día a Día," 30 Diciembre 2017. [Online]. Available: https://www.diaadia.com.pa/el-pais/usar-el-aire-acondicionado-le-pasarafactura-en-2018-331178. 